\title{
Globularifolin inhibits CAMA-1 human breast cancer cell line via cell cycle arrest, apoptosis and inhibition of PI3K/AKT signalling pathway
}

\author{
Yu Chen ${ }^{1}$, Zhenwu Wang ${ }^{2}$, Mei Liu ${ }^{1}$, Xiaodong Wang ${ }^{1 \star}$, Linghan Zhang ${ }^{3}$, Can \\ Gong ${ }^{1}$ \\ ${ }_{1}^{1}$ Department of Breast Surgery, ${ }^{2}$ Department of the Graduate's Training, ${ }^{3}$ Department of Surgery, West China Hospital, Sichuan \\ University, Chengdu, 610041, China
}

*For correspondence: Email: WGargilak@yahoo.com

Sent for review: 4 January 2018

Revised accepted: 22 August 2018

\begin{abstract}
Purpose: To investigate the anticancer activity of globularifolin against CAMA-1 breast cancer cells. Methods: The viability of CAMA-1 cells was assessed by MTT assay. DAPI and annexin V/PI staining were used for the determination of apoptotic cell death. Flow cytometry was employed for cell cycle analysis, while wound healing and immunoblotting assays were used to measure cell migration and protein expression, respectively.

Results: Globularifolin decreased the viability of CAMA-1 breast cancer cells dose-dependently, with half-maximal inhibitory concentration $\left(I C_{50}\right)$ of $10 \mu \mathrm{M}$, relative to its $I C_{50}$ of $65 \mu \mathrm{M}$ against non-cancerous CMMT breast cells. It also initiated apoptotic cell death and cell cycle arrest. Moreover, it inhibited the migration of CAMA-1 breast cancer cells, and PISK/AKT signalling cascade.

Conclusion: These results suggest that globularifolin has promising potential for use in the treatment of breast cancer.
\end{abstract}

Keywords: Breast cancer, Globularifolin, Apoptosis, Cell cycle, Cell migration

\begin{abstract}
This is an Open Access article that uses a funding model which does not charge readers or their institutions for access and distributed under the terms of the Creative Commons Attribution License (http://creativecommons.org/licenses/by/4.0) and the Budapest Open Access Initiative (http://www.budapestopenaccessinitiative.org/read), which permit unrestricted use, distribution, and reproduction in any medium, provided the original work is properly credited.

Tropical Journal of Pharmaceutical Research is indexed by Science Citation Index (SciSearch), Scopus, International Pharmaceutical Abstract, Chemical Abstracts, Embase, Index Copernicus, EBSCO, African Index Medicus, JournalSeek, Journal Citation Reports/Science Edition, Directory of Open Access Journals (DOAJ), African Journal Online, Bioline International, Open-J-Gate and Pharmacy Abstracts
\end{abstract}

\section{INTRODUCTION}

Breast cancer is one of prevalent cancers in women the world over. In the United States alone, it has been reported that one out of eight women is diagnosed with breast cancer [1]. About 400,000 breast cancer-related deaths are reported annually [2]. The heterogeneity of breast cancer poses a major impediment to its early detection [3]. Currently, breast cancer treatment involves surgery, chemotherapy and/or radiotherapy. However, despite recent progress in cancer research, the clinical outcomes are very poor [4].

Plant-derived natural products have been considered as prospective anticancer agents, and are therefore regularly screened for their anticancer properties. Globularifolin is one of the rare acylated iridoid glucosides isolated from some species of Plantaginaceae family $[5,6]$. Studies have shown that it exhibits an array of 
pharmacological properties. Recently, it was reported that it exhibited significant anticancer effects against glioma U87 cell line [7]. In the present study, the anticancer effects of globularifolin against CSAMA-1 breast cancer cell line was investigated.

\section{EXPERIMENTAL}

\section{Chemicals, reagents and culture conditions}

All chemicals and reagents were obtained from Sigma-Aldrich Company. Human breast cancer CAMA-1and non-cancerous CMMT cell lines were purchased from Type Culture Collection of Chinese Academy of Sciences, Shanghai, China. The cells were grown in RPMI-1640 with the composition $10 \%$ fetal bovine serum (FBS), and appropriate antibiotics and atmosphere of $5 \%$ $\mathrm{CO}_{2}$.

\section{Effect of globularifolin on proliferation of CAMA-1 cancer cells}

The proliferation rate of CAMA-1 cancer cells and CMMT cells was determined with MTT assay as described previously [8]. The cells were cultured in 96 -well plates at $5 \times 10^{3}$ cells per well. They were then incubated overnight, and the culture medium was changed and a fresh media with different concentrations of globularifolin (0$100 \mu \mathrm{M})$ was added.

After $24 \mathrm{~h}$, addition of MTT $(0.5 \mathrm{mg} / \mathrm{mL})$ was followed, and the wells were subjected to incubation 3-4 h. The absorbance was then taken at $570 \mathrm{~nm}$.

\section{Effect of globularifolin on apoptosis of CAMA-1 breast cancer cells}

The assessment of the nuclear morphology of CAMA-1 cells was done by fluorescence microscopy following DAPI treatment as described previously [9]. Ten fields with 100 cells/ field were selected randomly for estimation of cells with condensed nuclei. Annexin V/PI double staining was used for the determination of apoptotic CAMA-1 cancer cells by flow cytometry.

\section{Cell cycle analysis}

The distribution of the CAMA-1 cells in different cycle phases was performed by flow cytometry after PI stained by following the method reported in literature [9]. In brief, the CAMA-1 cells were grown in 6-well plates and treated with globularifolin for $24 \mathrm{~h}$. The cells then collected and PBS washed followed by fixation in ethanol
(70\%). After overnight incubation at $4{ }^{\circ} \mathrm{C}$, the cells were subjected to $\mathrm{PI}$ staining and subjected to flow cytometry.

\section{Wound healing assay}

The migration of CAMA-1 cells was determined with wound healing assay. The cells were grown to confluence, and a scratch was made with a scratching device. The cells were then incubated again for $48 \mathrm{~h}$, and the wound healing capacity was evaluated by comparing the widths of the wounds.

\section{Determination of protein expressions by western blotting}

After lysis of the CAMA-1 cells in RIPA lysis buffer, the protein content of the each lysates was estimated by BCA assay as described previously [10]. The samples were then loaded on the SDS-PAGE. The gels were then transferred to nitrocellulose membranes and subjected to treatment with primary antibody at 4 ${ }^{\circ} \mathrm{C}$ for a period of $24 \mathrm{~h}$.

After this the membranes were incubated with HRP-conjugated secondary antibody (1:1000) for 50 min at $25^{\circ} \mathrm{C}$. Enhanced chemi-luminescence reagent was used to visualise the protein bands.

\section{Statistical analysis}

The experiments were done in triplicate and the data is presented as mean \pm SD. GraphPad prism was employed to carry out the statistical analysis by student's t test and the values at $p<$ 0.05 were considered statistically significant.

\section{RESULTS}

\section{Globularifolin decreased the viability of CAMA-1 breast cancer cells}

The impact of globularifolin on cell proliferation was evaluated with MTT assay. The CAMA-1 cells were subjected to globularifolin treatment at varied concentrations $(0,5,10$ and $20 \mu \mathrm{M})$. The results of MTT assay revealed that globularifolin exhibited considerable and dose-dependent antiproliferative effects on CAMA-1 cells (Figure 1).

It was observed that the $\mathrm{IC}_{50}$ for the inhibition of CAMA- 1 cancer cells by globularifolin was 10 $\mu \mathrm{M}$, while its $\mathrm{C}_{50}$ for the inhibition of the noncancerous CMMT cells was $65 \mu \mathrm{M}$. These results clearly show that globularifolin selectively targets breast cancer cells. 
Globularifolin induced apoptosis in CAMA-1 breast cancer cells

Previously, it was reported that globularifolin could induce apoptosis in glioma cells [7]. Therefore, herein the impact of globularifolin on CAMA-1 breast cancer cell apoptosis was investigated. The CAMA-1 cells were first exposed to globularifolin at different concentrations, then subjected to DAPI staining, and finally observed under fluorescence microscope. The results showed that globularifolin induced apoptosis in CAMA-1 breast cancer cells, as was apparent from the increased number of cells with colourless nuclei (Figure 2). Annexin V/PI further revealed that the apoptotic cells were increased from $2.6 \%$ in control to $61.3 \%$ at $20 \mu \mathrm{M}$ of globularifolin (Figure 3).To further confirm apoptosis at the molecular level, the expressions of Bax and Bcl-2 proteins were assessed. It was found that globularifolin treatment enhanced Bax expression, but downregulated the expression of Bcl-2 expression in a dose-dependent manner (Figure 4).

\section{Globularifolin caused G2/M cell cycle arrest in CAMA-1 breast cancer cells}

The distribution of CAMA-1 cells in the different cell cycle phases after treatment with various concentrations of globularifolin was determined by flow cytometry. The results revealed that globularifolin caused accumulation of CAMA-1 in G2 phase, which ultimately led to G2/M cell cycle arrest (Figure 5).

\section{Globularifolin inhibited migration of CAMA-1 cells}

The inhibitory effect of globularifolin at $\mathrm{IC}_{50}$ on the migration of CAMA-1 breast cancer cells was determined by wound healing assay. The results showed that globularifolin considerably inhibited the migration of the CAMA-1 breast cancer cells (Figure 6).

\section{Globularifolin inhibited PI3K/AKT signalling pathway}

The PI3K/AKT signalling pathway is involved in the tumorigenesis of different cancer types [11]. Herein, the effect of globularifolin on the PI3K/AKT pathway was determined. It was found that globularifolin dose-dependently decreased expressions of $\mathrm{p}-\mathrm{PI} 3 \mathrm{~K}$ and $\mathrm{p}-\mathrm{AK}$. However, the expressions of $\mathrm{PI} 3 \mathrm{~K}$ and AKT remained almost unaltered (Figure 7).

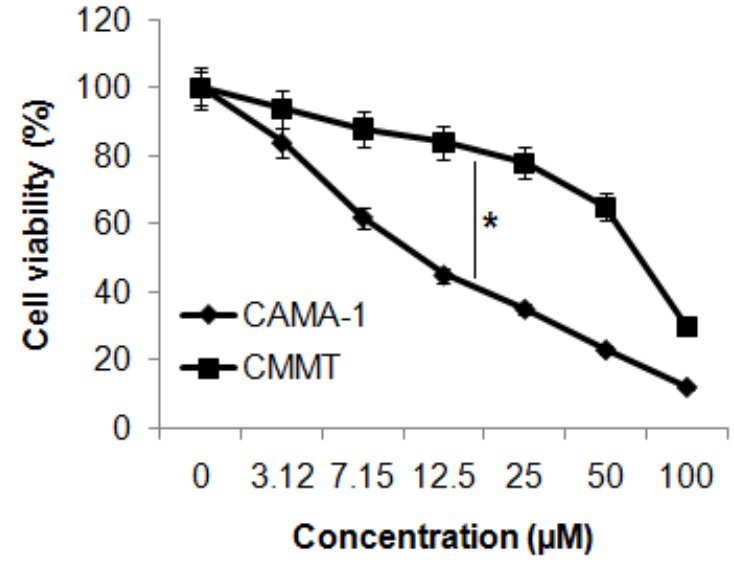

Figure 1: Effect of globularifolin on cell viability of CAMA- 1 and CMMT cells. The values are mean \pm SD $\left(\mathrm{n}=3,{ }^{*} p<0.05\right)$
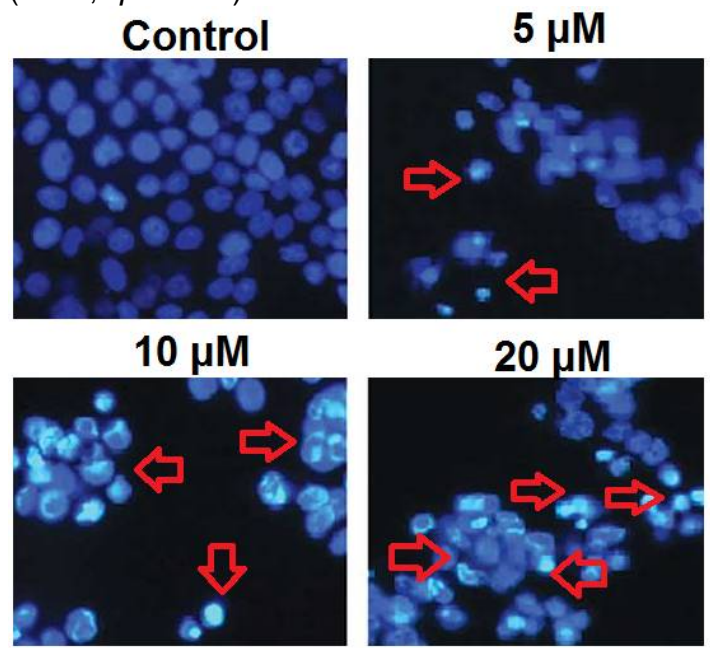

Figure 2: Effect of globularifolin on apoptosis of CAMA-1breast cancer cells. The experiments were carried in triplicate

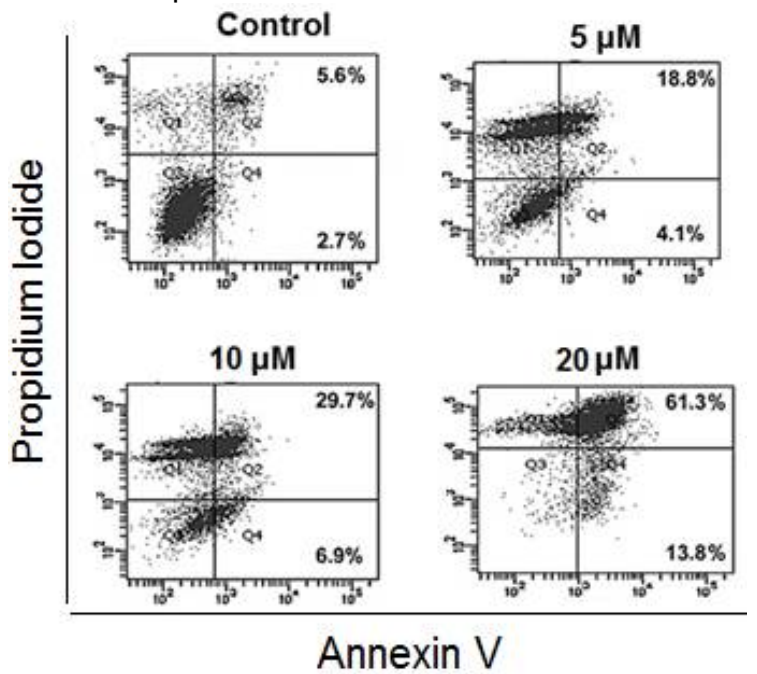

Figure 3: Percentage of apoptotic CAMA-1 cells, as depicted by Annexin V/PI staining. Experiments were carried in triplicate 


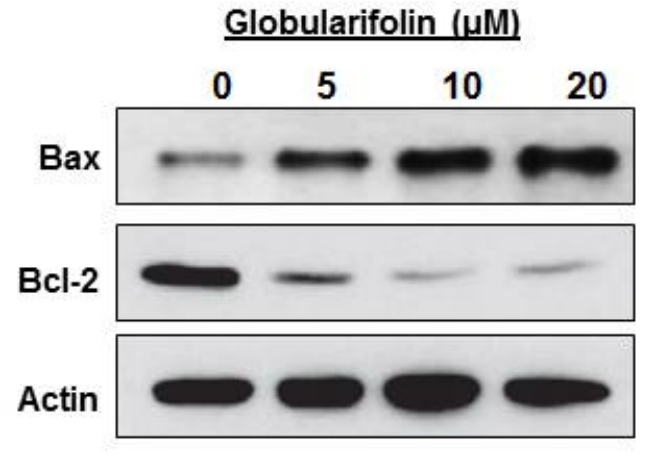

Figure 4: Effect of globularifolin on Bax and Bcl-2 expressions, as determined with western blotting. The experiments were carried in triplicate
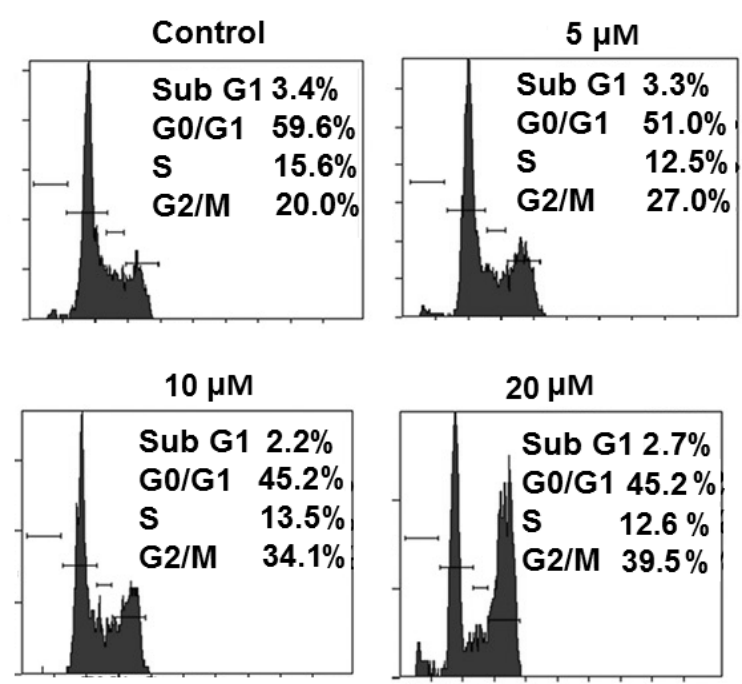

Figure 5: Effect of globularifolin acid on cell cycle distribution of CAMA-1 breast cancer cells. The experiments were carried in triplicate

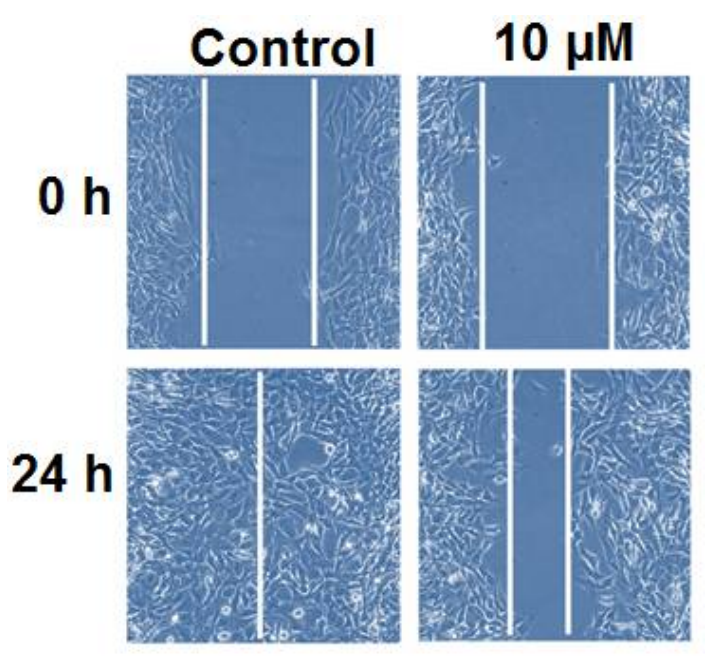

Figure 6: Effect of globularifolin on migration of CAMA-1 breast cancer cells, as assessed using wound healing. The experiments were carried in triplicate

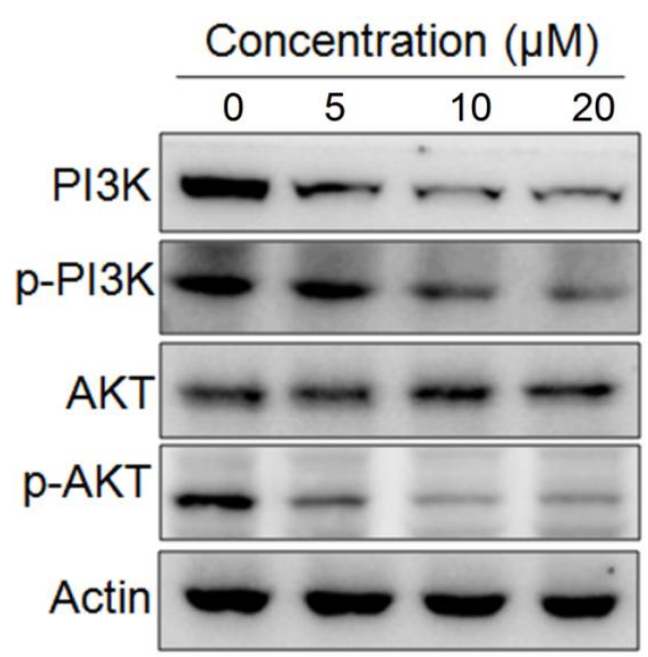

Figure 7: Effect of globularifolin on protein expressions of PI3K/AKT pathway in CAMA-1 cells, as determined using western blotting. The experiments were carried in triplicate

\section{DISCUSSION}

Breast cancer is one of the devastating cancers causing considerable mortality in women across the globe [12]. It is one of the frequently detected cancers in women, and is mostly diagnosed at the advanced stages due to the unavailability of reliable biomarkers [13]. Currently, the disease is managed with chemotherapy, but the available drugs are associated with a number of adverse side effects [14]. Over the years, plant-derived secondary metabolites have gained considerable attention as bioactive molecules. They have been shown to possess anticancer effects on different types of cancers [15].

Against this backdrop, this study was carried out to unravel the growth-inhibitory effects of globularifolin against CAMA-1 cells. The results showed that globularifolin exhibited considerable anticancer activity with an $\mathrm{IC}_{50}$ of $10 \mu \mathrm{M}$ against CAMA- 1 cells, as against its $\mathrm{C}_{50}$ of $65 \mu \mathrm{M}$ against normal CMMT breast cells. To further determine the mechanism of the anticancer effects of globularifolin, DAPI staining was performed and it was found that globularifolin exerted anticancer effects via induction of apoptosis. Moreover, the apoptotic effects of globularifolin were concentration-dependent, as was apparent from the annexin V/PI staining. Apoptosis is an important mechanism by which several chemotherapeutic drugs exert their antiproliferative actions [16]. These results are supported by reports from a previous investigation in which globularifolin was shown to trigger apoptosis in glioma cells [7]. Herein, the expressions of $\mathrm{Bax}$ and $\mathrm{Bcl}-2$ were determined to see if the globularifolin-induced apoptosis 
followed the mitochondrial pathway. Western blotting results revealed Bax expression was enhanced, while the Bcl-2 expression was suppressed in response to globularifolin treatment. Another important mechanism that has been reported to contribute to the anticancer effects of many well-known drugs is cell cycle arrest [17]. Some anticancer drugs halt the progression of cells from one phase of the cell cycle to another by targeting specific proteins, leading to the accumulation of cancer cells at a particular stage. Arrest of the cell cycle prevents the cancer cell from developing into tumours, and from spreading to other parts of the body [18]. Consistent with this, it was observed that globularifolin caused G2/M cell cycle arrest of CAMA-1 breast cancer cells in a concentrationdependent fashion. Anticancer agents that supress the migration of cancer cells have been reported to be important, since they can efficiently inhibit the metastasis of cancer cells [19].

It was also found that globularifolin efficiently inhibited the migration of CAMA-1 cancer cells. Earlier on, it was reported that many anticancer molecules target PI3K/AKT signalling pathway in cancer cells [9]. Therefore, the effect of globularifolin on the expressions of p-AKT, AKT, $\mathrm{p}-\mathrm{p}-\mathrm{PI} \mathrm{K}$ andPI3K was investigated. It was found that globularifolin decreased the expression of $p$ $\mathrm{PI} 3 \mathrm{~K}$ and $\mathrm{p}-\mathrm{AKT}$, indicating that the anticancer effects of globularifolin may in part, be due to blockage of the PI3K/AKT signalling pathway.

\section{CONCLUSION}

The findings of this study indicate that globularifolin possesses significant anticancer activity against CAMA-1 breast cancer through a mechanism that involves apoptosis, cell cycle arrest and inhibition of the PI3K/AKT signalling pathway. These results also suggest that globularifolin may be a promising lead molecule for development of an effective chemotherapy for breast cancer.

\section{DECLARATIONS}

\section{Acknowledgement}

The corresponding author acknowledges the Department of Breast Surgery, West China Hospital, Sichuan University, Chengdu, 610041, China for providing some of the facilities.

\section{Conflict of Interest}

No conflict of interest associated with this work.

\section{Contribution of Authors}

The authors declare that this work was done by the authors named in this article and all liabilities pertaining to claims relating to the content of this article will be borne by them.

\section{REFERENCES}

1. Bano R, Salim M, Khan Al, Zaidi A. Prognosis of breast cancer in very young age (less than 30 years). J Cancer Allied Spec 2016; 2: 1-7.

2. Van't Veer LJ, Dai H, Van De Vijver MJ, He YD, Hart AA, Mao M, Peterse HL, Van Der Kooy K, Marton MJ, Witteveen AT, Schreiber GJ. Gene expression profiling predicts clinical outcome of breast cancer. Nature 2002; 415: 530-536.

3. Slamon DJ, Godolphin W, Jones LA, Holt JA, Wong SG, Keith DE, Levin WJ, Stuart SG, Udove J, Ullrich A, et al. Studies of the HER-2/neu proto-oncogene in human breast and ovarian cancer. Science 1989; 244: 707-712.

4. Allison $K H$, Abraham LA, Weaver DL, Tosteson AN, Nelson HD, Onega T, Geller BM, Kerlikowske K, Carney $P A$, Ichikawa LE, Buist DS. Trends in breast biopsy pathology diagnoses among women undergoing mammography in the United States: a report from the Breast Cancer Surveillance Consortium. Cancer 2015; 121(9):1369-1378.

5. Kirmizibekmez H, Caliş I, Akbay P, Sticher O. Iridoid and bisiridoid glycosides from Globulariacordifolia. Z Naturforsch C 2003; 58: 337-341.

6. Albach DC, Grayer RJ, Jensen SR, Ozgokce F, Veitch NC. Acylated flavones glycosides from Veronica. Phytochem 2003; 64: 1295-1301

7. $Y u Y$, Fu $X$, Ran $Q$, Yang $K$, Wen $Y$, Li H, Wang $F$. Globularifolin exerts anticancer effects on glioma U87 cells through inhibition of Akt/mTOR and MEK/ERK signaling pathways in vitro and inhibits tumor growth in vivo. Biochimie 2017; 142: 144-151.

8. Lin C, Hu Z, Yuan G, Su H, Zeng Y, Guo Z, Zhong $F$, Jiang $K$, He S. MicroRNA-1179 inhibits the proliferation, migration and invasion of human pancreatic cancer cells by targeting E2F5. Chem Biol Interact. 2018: 291; 5771.

9. Liu JJ, Huang RW, Lin DJ, Peng J, Zhang M, Pan X, Hou $M, W u X Y$, Lin $Q$, Chen F. Ponicidin, an ent-kaurane diterpenoid derived from a constituent of the herbal supplement PC-SPES, Rabdosia rubescens, induces apoptosis by activation of caspase-3 and mitochondrial events in lung cancer cells in vitro. Cancer Invest. 2006; 24: 136-148.

10. Aubé M, Larochelle C, Ayotte P. 1, 1-dichloro-2, 2-bis ( $p$ chlorophenyl) ethylene ( $\left.p, p^{\prime}-D D E\right)$ disrupts the estrogen-androgen balance regulating the growth of hormone-dependent breast cancer cells. Breast Cancer Res 2008: 2; 16-24. 
11. Vara JÁ, Casado E, de Castro J, Cejas P, Belda-Iniesta C, González-Barón M. PI3K/Akt signalling pathway and cancer. Cancer Treat Rev 2004; 30(2): 193-204.

12. Kelsey JL, Berkowitz GS. Breast cancer epidemiology. Cancer Res 1988; 48(20): 5615-5623.

13. DeSantis C, Ma J, Bryan L, Jemal A. Breast cancer statistics, 2013. CA Cancer J Clin. 2014; 64: 52-62.

14. Spiegel D, Kraemer H, Bloom J, Gottheil E. Effect of psychosocial treatment on survival of patients with metastatic breast cancer. Lancet 1989; 334: 888-891.

15. Aadil Khursheed, Manzoor A Rather, Rafiya Rashid. Plant-based natural compounds and herbal extracts as promising apoptotic agents: their implications for cancer prevention and treatment. Adv Biomed Pharma 2016; 3 : 245-269.
16. Fisher DE. Apoptosis in cancer therapy: crossing the threshold. Cell 1994; 78(4): 539-542.

17. Evan Gl, Vousden KH. Proliferation, cell cycle and apoptosis in cancer. Nature 2001; 411: 342-348

18. Waldman $T$, Zhang $Y$, Dillehay $L, Y u J$, Kinzler $K$, Vogelstein B, Williams J. Cell-cycle arrest versus cell death in cancer therapy. Nature Med 1997; 3: 10341036.

19. Jones DH, Nakashima T, Sanchez OH, Kozieradzki I, Komarova SV, Sarosi I, Morony S, Rubin E, Sarao R, Hojilla CV, Komnenovic V. Regulation of cancer cell migration and bone metastasis by RANKL. Nature 2006; 440: 692-696. 